\title{
THE COOPERATIVE GAME-THEORETIC MODEL OF STABLE BENEFITS DISTRIBUTION FROM IT SOLUTION IMPLEMENTATION
}

\author{
A.A. Grigoreva1', grigoreva_spb@list.ru, \\ A.T. Latipova ${ }^{2}$, latipovaat@susu.ru \\ ${ }^{1}$ Peter the Great St. Petersburg Polytechnic University (SPbPU), St. Petersburg, \\ Russian Federation, \\ ${ }^{2}$ South Ural State University, Chelyabinsk, Russian Federation
}

\begin{abstract}
Nowadays there are a large number of methods to estimate the efficiency of IT solutions and the effectiveness of IT project activities. Despite the existing variety of methods to assess the benefits from IT, they are not sufficient to prevent troubles caused by the situation where the launch of the project is hindered by a part of stakeholders who are uncertain about further benefits distribution or even they are afraid of the possibility about negative impact of the new IT solution on the performance indicators of departments in their subordination.

This article presents the results of the modelling the business and IT coalitions interaction while enterprise architecture development projects at the stage of choosing and approving the new IT solution. The function to measure the IT solution benefits taking into account the financial and qualitative components of benefits, the efforts of the each coalition project participation and project costs is determined. A game-theoretic model of decision-making while choosing and approving the new IT solution with objectives to incorporate the agents into one big coalition with a stable resources distribution is stated. Practical application of the developed model will allow increasing IT project efficiency in corporate structures.

Keywords: cooperative game, distribution problem, benefits from IT solutions, enterprise architecture development project, Core, Shapley value, IT service, IT management.
\end{abstract}

\section{Introduction}

Practical business shows that many IT initiatives that require significant changes in the existing Enterprise Architecture (EA) are not implemented. According to many experts, one of the obvious reason for this is the interaction between developers and stakeholders and the presence of a "human factor" $[1-3]$.

In the theory of stakeholders it is noted [4] that managers of various departments (under the department is understood operationally independent functional units of the enterprise) are inclined to focus on achieving their own local goals, and only after them on the global goals of the whole enterprise. Mismatch for the purposes of different stakeholders is a source of conflict [5]. To prevent the conflict just an exchange of information between the stakeholders involved in the implementation of the project is not sufficient, stakeholders are jointly to choose and assess the proposed distribution of benefits from implementation.

Thus, in this article, we hypothesize that before launching an IT project of implementing an economically reasonable IT solution, each coalition of stakeholders involved in project development should be acquainted with the benefits that they receive after implementing the solutions. This will contribute to avoiding the difficulties caused by the opportunistic behaviour of some stakeholders who are dissatisfied with the launch of EA development projects.

The task of ensuring the alignment of interests within the stakeholder group in a new architectural solution (AS) selecting process and adopting it in implementation in the existing IT architecture is reduced to the tasks of an integrated assessment of the benefits from implementation and their subsequent distribution among the involved departments in the organization. This problem can be solved using the methods of game theory through modelling socioeconomic systems when making decisions or distributing costs / benefits as the game theory methods allow finding equilibrium states and effective distributions in situations of randomness, incompleteness of information and uncertainty, contradiction and conflict of interests. 
In this paper we divide the task of ensuring the consistency of the development and implementation of IT solutions into the following stages:

- identification of stakeholders, departments and evaluation a group influence;

- evaluation of the input parameters of the task;

- choosing the best solution for the task;

- formal assessment of stakeholders benefits from implementation of the solution;

- redistribution of benefits.

The task of ensuring the consistency of stakeholders interests during EA project is to answer the main research question: how should be the benefits of implementing IT solutions allocated among stakeholders and relevant departments so that the selected IT solution is accepted for implementation be the group.

\section{The game-theoretic approach in the distribution problem}

Definition of a cooperative game. According to the definition in [6], the coalitional game consists of a finite set of players $I=\{1,2, \ldots, n\}$ called the grand coalition and a characteristic function $v: 2^{I} \rightarrow R$ from the set of all possible coalitions of players to a set of payments that satisfies $v(\varnothing)=0$. The function describes how much collective payoff a set of players can gain by forming a coalition, and the game is sometimes called a value game or a profit game.

Problem formulation according to EA project. The set $I=\{1,2, \ldots, n\}$ is a finite set of influence groups (consisting of stakeholders and departments) wishing to improve their performance by introducing new IT solutions. $E_{i}$ - is the monetary (financial) indicators of the allocated $i$-th group of influence ( $i \in I$ ), $Q_{i}$ - non-monetary (qualitative) indicators for the $i$-th group. We take $v_{i}$ as a function of the gains of the $i$-th group, depending on the qualitative and financial criteria $v_{i} \sim\left(E_{i}, Q_{i}\right)$. Participants of the $i$-th group, entering into the project interaction and investing efforts and time in quantity $D_{i}\left(D_{i}>0\right)$, after the introduction of the solution, strive to obtain with the project results an additional flow of the benefits, the value of which is not less than the amount of effort:

$$
\begin{aligned}
& \Delta v_{i}\left(E_{i}, Q_{i}\right) \geq D_{i}, \\
& v_{i}=v_{i}^{0}+\Delta v_{i},
\end{aligned}
$$

where $v_{i}^{0}$-is the value of the benefit function for the $i$-th group before investing efforts in the project.

The set $I$ can be divided into disjoint subsets (coalitions) $N$ of the form:

$$
\begin{aligned}
& I=I_{1} \cup I_{2} \cup \ldots \cup I_{N}, \\
& \forall(j, k):\left\{(j=(\overline{1, N}) ; k=(\overline{1, N})), j \neq k|| I_{j} \cap I_{k}|=\varnothing,| I_{j}|\geq 1,| I_{k} \mid \geq 1\right\},
\end{aligned}
$$

each of which $I_{1}, I_{2}, \ldots, I_{N}$ in their turn can be further divided into subsets similarly to a set $I$ until there is no more than one participant (influence group): $\left(\left|I_{j}\right| \geq 1\right)$. Thus, not one of the participants can belong to two sets (coalitions) simultaneously, but must belong to one single set (coalition).

All influence groups strive with the introduction of a new solution to increase the profit indicators, which can be represented as a multicriteria optimization problem:

$$
v_{i}\left(E_{i}, Q_{i}\right) \rightarrow \max , i \in I \text {. }
$$

If the influence groups have entered into a grand coalition, the goal of the coalition will be to maximize the total benefit of all members of the coalition:

$$
\sum_{i \in I} v_{i}\left(E_{i}, Q_{i}\right) \rightarrow \max
$$

The total benefit from the project, taking into account the costs of effort and total costs of implementation is determined as follows:

$$
v(I)=\left[\sum_{i \in I} v_{i}^{0}+q_{i} *\left(a_{i} E_{i}+b_{i} Q_{i}-D_{i}\right)\right]-C,
$$

where

$v_{i}^{0}-$ the value of the benefit function for the $i$-th group before investing in the implementation of 


\section{Краткие сообщения}

the project, i.e. how much the participant earns for today / will earn (the discounted profit of corresponding departments) without introduction of the solution;

$E_{i}$ - financial benefits from implementation;

$Q_{i}$ - quality benefits from implementation;

$D_{i}-$ a cost evaluation of the efforts made by the group in the project;

$a_{i}, b_{i}$ - indexes of priority of monetary and qualitative components of benefits for the $i$-th group depending on the market situation;

$C$ - the cost amount of the project development and maintenance activities on a time basis, taking into account the correlation with the value of development efforts $D_{i}$;

$q_{i}$ - the index of significance for the $i$-th group (based on the level of interest and the degree of stakeholders power to influence the decision making).

To conclude, $v(I)$ is a summary of a total value of the monetary and non-monetary benefits of the project results, minus the value of efforts of the groups and the total project costs over a certain time interval.

\section{Mathematical model of the problem of sustainable distribution} of benefits from implementation

The mathematical model of the task of confirming the proposed AS to be implemented by the stakeholders and departments by uniting into a large coalition with a stable allocation of resources is recorded as follows:

$$
\begin{aligned}
& \sum_{i \in I} v_{i}\left(E_{i}, Q_{i}\right) \rightarrow \max , \\
& \left\{\begin{array}{l}
\sum_{i \in I} x_{i}=v(I), \\
(\forall i \in I): x_{i} \geq v_{i}^{0},
\end{array}\right.
\end{aligned}
$$

where $x_{i}$ - are the benefits to be transferred to the group with the allocation of the total benefit from the project.

Stable [7] distributing the benefits of the project implementation between the involved departments is the vector of benefits so that neither party do experience loss or fall of its performance indicators and do not want to separate from the coalition.

Benefits function is defined as a discrete function of qualitative and quantitative indicators of IT solution from the point of view of various managers of the company (stakeholders). When making decisions, managers usually focus primarily on their own benefits (individual motivation) either than on the global company goals. Note that different criteria may have different significance for the organization at different stages of its development; therefore, when assessing the benefits of implementation, it is necessary to introduce the importance coefficients of various criteria.

For each coalition member, it is acceptable to have your own approach to estimating the parameters for calculating the total benefit function. For example, in the case of project evaluation by financial managers, the qualitative benefits of implementation can be equated to zero $\left(b_{i}=0\right)$.

The condition for applying this model in practice is to bring all indicators of benefits, both qualitative and quantitative, to a monetary equivalent, in order to ensure the possibility of further reallocation of benefits between group members.

The requisitions of the model of fair distribution of benefits from the implemented IT solution between involved in EA changes stakeholders are as following:

- A fixed number of agents (players) representing functional departments of firms participating in the project;

- The project will take place only with the participation of all agents. The structure of the project team is constant and predetermined;

- Each of the agents maximizes its profit and operates in a cooperative environment;

- Information Technology Department (ITD) has a leading role in deciding whether to launch the project or not depending on its correspondence to IT strategy; 
- The benefits of each department after project has finished should be no less than the benefits existing without the IT solution;

- The model is dynamic - considering the decision making at two moments of time. At the first stage, there is a game interaction between the IT and Business Unit (BU) coalitions, and then the game interaction between $\mathrm{BU}$ members about benefits distribution.

\section{Modeling the interaction between business and IT coalitions}

Consider the situation of making a decision about the EA project launch, i.e. the task of selecting the requirements to a target EA within the coalition of business stakeholders and its acceptance for development by the ITD. In the game $n=2$, there are three possible coalitions, each of which is characterized by a characteristic function that matches each coalition to the amount of benefits that it can earn independently:

$I=\{I T D, B U\}-$ a set of stakeholders;

$v_{B U}^{0}$ - profit BU without introduction of AS;

$v_{I T D}^{0}-$ ITD profit without selling an architectural solution as an IT service;

$v(B U \cup I T D)$ - total profit BU and ITD with the implemented solution, which can be calculated as the sum of the profit of each of the agents increased for the effect from the introduction of the AS in timely bases;

$x_{B U}-\mathrm{BU}$ component of the winning vector from the implementation of the AS;

$x_{I T D}$ - ITD component of the winning vector from the AS implementation.

Under the fair allocation of benefits between stakeholder groups, we mean the Pareto-optimal allocation of benefits from the implementation of AS. If there is any sharing that can increase the benefits of implementation for a group, without impairing the position of the other player, then the community of players will abandon the current sharing in favor of a better possible variant.

$$
\begin{aligned}
& v(I)=v\left(E_{B U}, Q_{B U}\right)+v\left(E_{I T D}, Q_{I T D}\right), \\
& \left\{\begin{array}{l}
x_{B U}+x_{I T D}=v(I)=v(B U \cup I T D), \\
x_{B U} \geq v_{B U}^{0}, x_{I T D} \geq v_{I T D}^{0} .
\end{array}\right.
\end{aligned}
$$

To ensure the possibility of benefits reallocation, they must be reduced to a single equivalent, for example, the transferable utility can be reduced to the discounted profit of each department.

If the project is not implemented or does not bring any positive effect for the participants that corresponds to the negative outcome. In this case, participants will not get any effect from the efforts invested in the project development $x_{B U}=v_{B U}^{0}, x_{I T D}=v_{I T D}^{0}$.

Otherwise, we get the Core, Pareto-optimal allocation are located on the boundary of the set and are given by a line segment $x_{B U}+x_{I T D}=v(I)=v(B U \cup I T D)$ whose points satisfy the constraint $x_{B U} \geq v_{B U}^{0}, x_{I T D} \geq v_{I T D}^{0}$. To obtain an unambiguous solution on a given segment, sharing is to be chosen that takes into account the contribution of each of the departments - Shapley Value (Fig. 1).

The Shapley value is one way to distribute the total gains to the players, assuming that they all collaborate. It is a "fair" distribution in the sense that it is the only distribution with certain desirable properties listed below. According to the Shapley value, the amount that player $i$ gets given in a coalitional game:

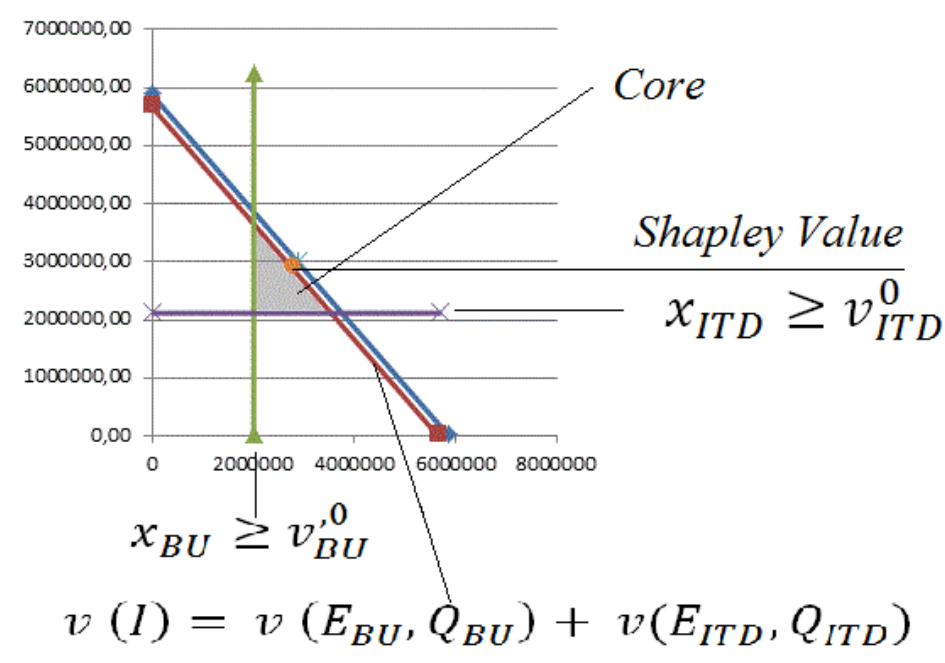

Fig. 1. Core and the Shapley Value. Source: compiled by the author 


$$
x_{i}=\sum_{i \in K} \frac{(n-k) !(k-1) !}{n !}\left(v_{K}-v_{K-i}\right) \text {, }
$$

$v(I)$ is the value of the gross profit of a grand coalition, $v_{K-i}$ is the value of the total profit of a large coalition without a participant $i, n$ is the number of participants in a grand coalition, $k$ is the number of coalition members $K, v_{K}$ is the potential result of a coalition $K, v_{K-\mathrm{i}}$ is the potential result of coalition $K$ without the player $i$.

The formula can be interpreted as follows: imagine the coalition being formed one actor at a time, with each actor demanding their contribution $\left(v_{K}-v_{K-i}\right)$ as a fair compensation, and then for each actor take the average of this contribution over the possible different permutations in which the coalition can be formed.

\section{Conclusion}

The article highlights a new class of tasks at the initial IT project stage: assessment of needs and redistribution of benefits between stakeholders who are involved in the project and affected of its results. A mathematical model of the distribution of benefits consisted of the monetary and qualitative components, as well as the costs of effort are proposed. The formulated requirement to monetary form of all benefits will ensure the transferability meaning of the target functions and KPIs involved in the project development departments. Within the framework of the developed method, the task of formalizing stakeholder interaction in terms of constructed mathematical models is solved. The obtained results allow increasing the level of quality and results of architectural projects.

\section{References}

1. Lankhorst M.M. Enterprise Architecture Modelling - the Issue of Integration. Advanced Engineering Informatics, 2004, vol. 18, no. 4, pp. 205-216. DOI: 10.1016/j.aei.2005.01.005

2. Nakakawa A., Bommel P., Proper H.A. Challenges of Involving Stakeholders when Creating Enterprise Architecture. 5th SIKS/BENAIS Conference on Enterprise Information Systems, 2010, pp. $43-55$.

3. Smolander K., Päivärinta T. Describing and Communicating Software Architecture in Practice: Observations on Stakeholders and Rationale. International Conference on Advanced Information Systems Engineering, Springer Berlin Heidelberg, 2002, pp. 117-133. DOI: 10.1007/3-540-47961-9_11

4. Freeman R.E., McVea J. A Stakeholder Approach to Strategic Management. The Blackwell Handbook of Strategic Management, 2001, pp. 183-201. DOI: 10.1111/b.9780631218616.2006.00007.x

5. Jensen M.C. Value Maximization, Stakeholder Theory and the Corporate Objective Function. Journal of Applied Corporate Finance, 2010, vol. 22, no. 1, pp. 32-42. DOI: 10.1111/j.17456622.2010.00259.x

6. Von Neumann J., Morgenstern O. Theory of Games and Economic Behavior (Commemorative Edition). Princeton University Press, 1990. 666 p.

7. Petrosyan L.A. [Stability of Solutions of Differential Games with Many Participants]. Bulletin of Leningrad University. Series 1: Mathematics, Mechanics, Astronomy, 1977, no. 19, pp. 46-52. (in Russ.)

Received 20 May 2018 


\title{
ТЕОРЕТИКО-ИГРОВАЯ МОДЕЛЬ КООПЕРАТИВНОГО РАСПРЕДЕЛЕНИЯ ВЫГОД ОТ ВНЕДРЕНИЯ ИТ-РЕШЕНИЙ
}

\author{
А.А. Григорьева ${ }^{1}$, А.Т. Латипова ${ }^{2}$ \\ ${ }^{1}$ Санкт-Петербургский политехнический университет Петра Великого (СПбПУ), \\ г. Санкт-Петербург, Россия, \\ ${ }^{2}$ Южно-Уральский государственный университет, г. Челябинск, Россия
}

\begin{abstract}
Несмотря на многообразие разработанных методик оценок выгод от ИТ (информационных технологий), они оказываются недостаточными в ситуациях, когда экономическая эффективность внедрения подтверждена и выбрана лучшая из предложенных альтернатив, но запуск проекта терпит препятствия со стороны стейкхолдеров, которые не имеют точных данных по перераспределению выгод от внедрения или даже опасаются негативного влияния нового решения на показатели эффективности отделов в их подчинении.

В статье представлены результаты моделирования взаимодействия внутренних коалиций бизнес- и ИТ-стейкхолдеров в проектах развития архитектуры предприятия на этапе принятия к внедрению нового ИТ-решения. Определяется целевая функция выгод от реализации проекта с учетом финансовой и качественной составляющих выгод, издержек на усилия проектного участия каждой коалиции и затрат на разработку. Строится теоретико-игровая модель принятия решения ко внедрению за счет объединения агентов в общую коалицию с устойчивым распределением ресурсов. Применение данной модели повысит эффективность реализации проектов в корпоративных структурах.

Ключевые слова: кооперативная игра, задача распределения, выгоды от ИТ-решений, проекты развития архитектуры предприятия, С-ядро, вектор Шепли, служба ИТ, корпоративное управление ИТ.
\end{abstract}

\section{Лumepamypa}

1. Lankhorst, M.M. Enterprise Architecture Modelling - the Issue of Integration / M.M. Lankhorst // Advanced Engineering Informatics. - 2004. - Vol. 18, no. 4. - P. 205-216. DOI: 10.1016/j.aei.2005.01.005

2. Nakakawa, A. Challenges of Involving Stakeholders when Creating Enterprise Architecture / A. Nakakawa, P. Bommel, H.A. Proper // 5th SIKS/BENAIS Conference on Enterprise Information Systems. - 2010. - P. 43-55.

3. Smolander, K. Describing and Communicating Software Architecture in Practice: Observations on Stakeholders and Rationale / K. Smolander, T. Päivärinta // International Conference on Advanced Information Systems Engineering. - Springer Berlin Heidelberg, 2002. - P. 117-133. DOI: 10.1007/3-540-47961-9 11

4. Freeman, R.E. A Stakeholder Approach to Strategic Management / R.E. Freeman, J. McVea // The Blackwell Handbook of Strategic Management. - 2001. - P. 183-201. DOI: 10.1111/b.9780631218616.2006.00007.x

5. Jensen, M.C. Value Maximization, Stakeholder Theory and the Corporate Objective Function / M.C. Jensen // Journal of Applied Corporate Finance. - 2010. - Vol. 22, no. 1. - P. 32-42. DOI: $10.1111 / j .1745-6622.2010 .00259 . x$

6. Von Neumann, J. Theory of Games and Economic Behavior (Commemorative Edition) / J. Von Neumann, O. Morgenstern. - Princeton University Press, 1990. - $666 \mathrm{p}$.

7. Петросян, Л.А. Устойчивость решений дифференциальных игр со многими участникали / Л.А. Петросян // Вестник Ленинградского университета. Серия 1: математика, механика, астрономия. - 1977. - №. 19. - C. 46-52. 
Григорьева Анастасия Александровна, аспирант Высшей школы управления и бизнеса, Санкт-Петербургский политехнический университет Петра Великого (СПбПУ), г. СанктПетербург; grigoreva_spb@list.ru.

Латипова Алина Таиховна, канд. физ.-мат. наук, доцент, заместитель директора по учебной работе Высшей школы электроники и компьютерных наук, Южно-Уральский государственный университет, г. Челябинск; latipovaat@susu.ru.

Поступила в редакцию 20 мая 2018 г.

\section{ОБРАЗЕЦ ЦИТИРОВАНИЯ}

Grigoreva, A.A. The Cooperative Game-Theoretic Model of Stable Benefits Distribution from IT Solution Implementation / A.A. Grigoreva, A.T. Latipova // Becтник ЮУрГУ. Серия «Компьютерные технологии, управление, радиоэлектроника». - 2018. - Т. 18, № 3. C. $150-156$. DOI: $10.14529 /$ ctcr180316

\section{FOR CITATION}

Grigoreva A.A., Latipova A.T. The Cooperative Game-Theoretic Model of Stable Benefits Distribution from IT Solution Implementation. Bulletin of the South Ural State University. Ser. Computer Technologies, Automatic Control, Radio Electronics, 2018, vol. 18, no. 3, pp. $150-156$. DOI: $10.14529 /$ ctcr 180316 